\section{$29812 \%$ CHEMICAL CONSTITUTION AND BIOLOGICAL ACTIVITY}

$\mathrm{P}$ ROGRESS in the interpretation of biological results in terms of chemical constitution is very slow. Except in chemotherapeutic investigations, attempts to corplo physical and chemical data

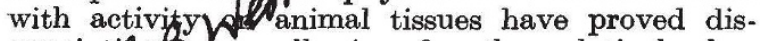
appointigh Soven allowing for the relatively low degree 4 accuracy in biological methods and the too fredpent absence of specific knowledge of the mode of action.

At the present time some advances have been made by using drugs belonging to a homologous series, or containing different elements but possessing varying degrees of similar pharmacological activity. Furthermore, lines of research have been directed with drugs having similar structures but showing protagonist and antagonist action. When Dr. F. Bergel delivered his address on "Some Aspects of the Relationship between Chemical Constitution and Physiological Activity" to the Fine Chemicals Group of the Society of Chemical Industry on November 26, 1948, at the London School of Hygiene and Tropical Medicine, he mentioned that too much must not be expected from one or two series of data disclosing only a fraction of the overall constitution. Once a working hypothesis of mechanism of action is established, correlation should be attempted between physico-chemical measurements and biological activities.

During the course of his address, Dr. Bergel showed that, in the consideration of the validity of the expression connecting physiological action of a drug and its chemical constitution (Crum-Brown and Fraser, 1869), it is necessary to include those events which precede visible pharmacological effects. The picture is confusing; but two working hypotheses help to elucidate the mechanism of drug action. In the first or receptor theory, certain areas of the cell at the site of action combine with the drug, and these combinations are the cause of the biological action. Many drugs such as anæsthetics, analgesics, and autonomic derivatives, acting rapidly and in high dilutions, may find their receptors on the outside of the cell surface, while those influencing cell division or growth may react with constituents of the protoplasm. Methylene blue, with its atropinelike and anti-bacterial effects, provides a clear example of both external and internal reactions. In the second or enzyme receptor theory (supported experimentally by such work on B.A.L., inhibitors of cholinesterases, respiratory enzyme systems, and amino-oxidases), a number of these receptors are said to be identical with functional enzymes or proteins. Then, on the basis of competitive affinity and mass action, an explanation is possible for the selective potency of stereoisomers, the increase of activity in homologous series, and the antagonistic action of certain drugs similar to protagonist molecules. The fact that low concentrations of many substances may produce physiological stimulation or depression while higher concentrations cause the reverse effect is, however, not easy to explain.

Turning to the chemical side, Dr. Bergel stressed that, only with models based on correct inter-atomic distances, van der Waals radii and valency angles, apart from geometrical and optical isomerism, can the compactness and spatial distribution of the atomic aggregate be appreciated. In addition, the
February 19, 1949 Vol. 163

existence of electrovalent, covalent and co-ordinate bonds, lone electron pairs, bonds with dipole moments adding up to polar groups and to polarization of the molecule, oscillating dipoles, resonance and hydrogen bonding, must not be forgotten. It has already been shown in some series that a certain bond-distance appears to be optimal for maximal effects. But dis. appointing results have been obtained from other aspects, and pharmacological chemists have therefore had to rely on rather more empirical approaches. The aim has often been to find a pharmaco-dynamic group, that is, the structural minimum which still carries distinct activity, and this type of method is well illustrated by work on synthetic analgesics, such as morphine substitutes.

G. B. WEST

\section{GERMAN SOCIETY FOR $20 \%$ DOCUMENTATION}

\section{CONFERENCE AT COLOGNE}

BEFORE the Second/4prld War, the International Federation NPr Rocug intation, then the Inter. national Instifule of Ifocumentation, included a German sedtion which, afterwards, was converted into a phat German ffair under the Nazi regime. A conderence of 1 (D) Deutsche Gesellschaft für Dokumentation tola place in Salzburg in 1942.

During December 9-10, 1948, at Cologne, another conference was held, the first since the War, with the aim of finding the way back to the broader outlook which might once again open up possibilities of international co-operation in the field of documentation. It was a re-organised Deutsche Gesellschaft für Dokumentation which sponsored this Conference, together with the Deutsche Normenausschuss, the Verband der Bibliotheken von Nordrhein-Westfalen, the Arbeitsgemeinschaft der Technisch-Wissenschaftlichen Bibliotheken and the Verein Deutscher Archivare. The Conference was attended by some 150-200 delegates from different parts of Germany, representing universities, libraries, learned societies, the legal profession, designers of apparatus. and industrial bodies, meeting on board a middle-size river boat equipped as hotel and restaurant.

The opening session was presided over by Prof. Schmölders, who welcomed the delegates on behalf of the rector of the University of Cologne, Prof. Kroll. The main speakers of this session were Dr. Vollmer, director of the Staatsarchiv at Düsseldorf, and Prof. Corsten, director of the Stadt- und Universitäts-bibliothek at Cologne. It was followed by a business meeting of the newly constituted society, election of officers, the formation of sub. committees and so on. Lectures, open to the public, were given at the University of Cologne by Dr. W. Schürmeyer, president of the Deutsche Gesellschaft, Mrs. L. Moholy, representing the Library Association and the Royal Photographic Society of Great Britain, and Dr. Pierre Bourgeois, director of the Bibliothèque Nationale Suisse.

The emphasis of the lectures, papers and sub. sequent discussions was on the various aspects of microphotography, its growth and development, its progress in different countries, its use in archives, libraries and bibliographical centres, its importance for scholars, scientific and research workers, the copyright position, and so on. Two copyright experts, Dr. O. Runge and Dr. Wildt, 